\title{
The symbolic meaning of the Sandeq boat making process among the Mandarese
}

\author{
Alem Febri Sonni ${ }^{1 *}$, Muhammad Amrullah $^{1}$, Tuti Bahfiarti ${ }^{1}$ \\ ${ }^{1}$ Department of Communication, Faculty of Social and Political Sciences, Hasanuddin University, \\ Indonesia.
}

*Corresponding Author:afsonni@gmail.com

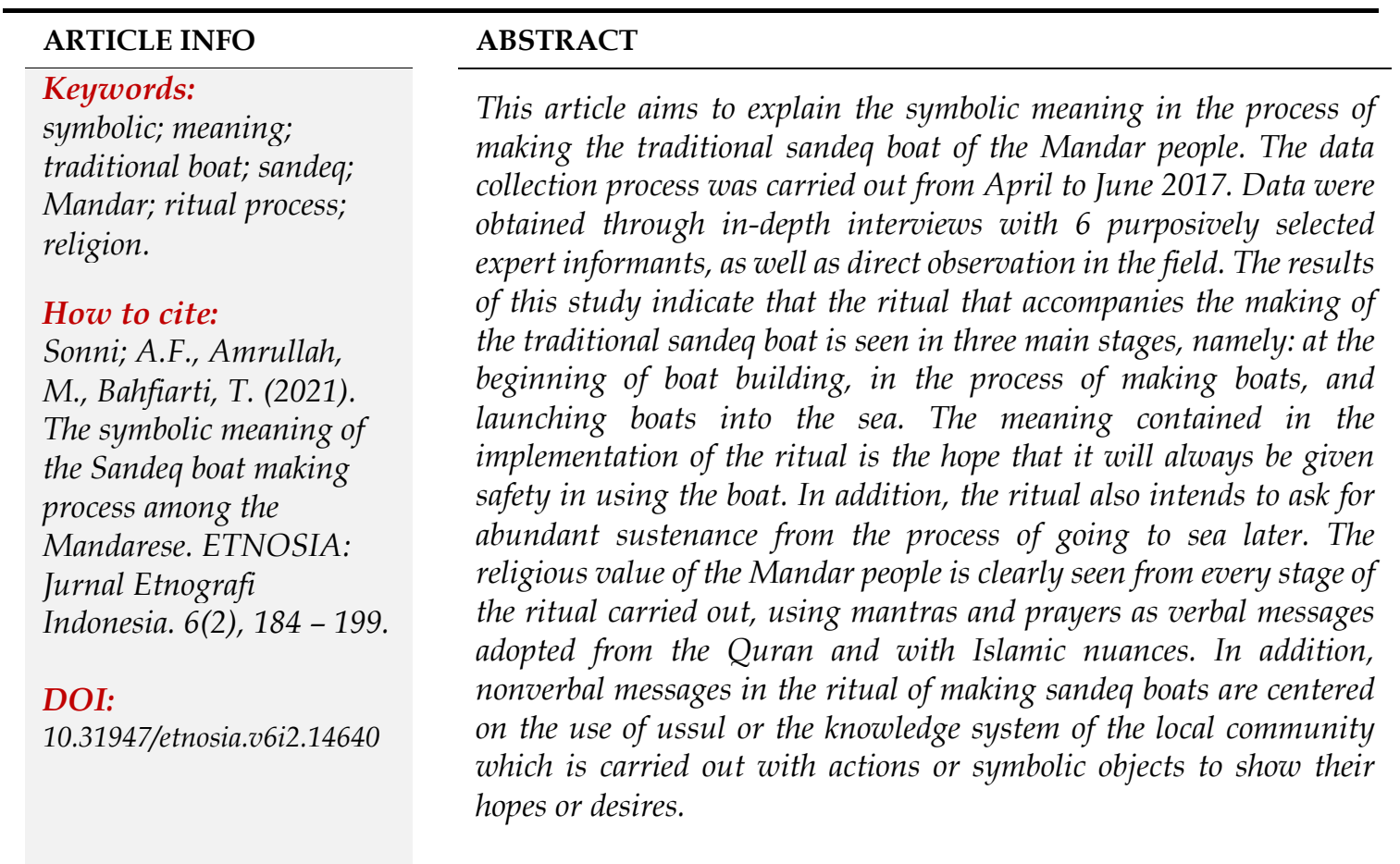

\section{Introduction}

The term Maritime is one of the cultural elements that is entrenched in the soul of the Indonesian nation. Maritime culture birthed various marine means of transportation, such as boats in various types, and forms according to their uses.

The most well-known traditional means of sea transportation originating from Sulawesi is the Pinisi. This legendary ship has become a historic symbol of the maritime power of the people of South Sulawesi. In addition, there are many more traditional boats such as lambok, bago, palari, salompong, and sandeq that have enlivened sea traffic from the archipelago to foreign countries. 
The people of the western region of South Sulawesi (the region now known as the province of West Sulawesi) have been known as great sailors since ancient times. One of the symbols of the greatness of sailors in the West Sulawesi region is the sandeq boat ${ }^{1}$. The existence of the traditional sandeq boat was only seen in the early 1930s. It was a researcher from Germany, Horst $\mathrm{H}$ Liebner, who then glanced at the beauty of this sandeq boat as a cultural manifestation that needs to be preserved. Furthermore, Liebner assesses that there is no traditional boat as strong and as fast as the sandeq, and is considered the fastest traditional boat ever in Austronesia.

The sandeq boat is not only a cultural heritage but is also one of the characteristic portraits of the Mandar people themselves, which reflects balance, simplicity, beauty, speed, accuracy, and toughness (Kasitowati, 2011). Therefore, if examined carefully, it will be seen that both in the sandeq boat and the procession that accompanies the making of the boat, there are noble values that live and develop in the Mandar people. Viewed from a cultural perspective, the uniqueness of the sandeq boat can be seen from the characteristics in technology and the mindset of making sandeq boats as a knowledge system that comes from community culture.

The birth of the sandeq boat is a manifestation of the Mandar people's reading of nature accompanied by an understanding of noble values that are firmly held throughout history. The cultural values of the Mandar people are ingrained in the making of sandeq boats, so that it is not only a means of fishing or transportation but also as a form of culture from the Mandar people. What is also interesting about the process of making traditional sandeq boats is a number of ritual activities or traditional ceremonial processions that accompany the making of the boat. A series of activities carried out both before manufacture, such as selecting trees to the stage before going down to the sea, is carried out with a series of certain traditional rituals that are firmly held by the Mandar people and have been carried out for generations. As an illustration of the uniqueness of the ritual of making sandeq boats is the ritual procession that is carried out when taking wood as material for making boats. Everyone who takes part in the harvesting of wood is required to follow the procession by taking the fallen leaves under the tree that will be cut down. The leaves are rubbed against their bodies, this is a sign that how the initial introduction to the tree that will be felled. After that dig the soil as deep as the index finger as a symbol of the unification of the body's senses with the ground. When they are about to be lowered into the sea, apart from reading the prayer they believe, the fishermen prepare some food as a form of alms, such as sokkol (a typical food made from sticky rice) which is made from three types of glutinous rice, namely red, white and black. Several eggs as well as a number of bananas of various types must be prepared in this procession. This shows that the sandeq boat as a means of living for fishermen cannot be separated from things that mystical (irrational).

The author is interested in conducting research, especially from a communication perspective, to examine the implicit meaning in the process of making sandeq boats. Not

1 Sandeq boat is an icon of the maritime greatness of the Mandar people. The greatness of the skilled sailors of Mandar is evidenced by the voyage using this outrigger boat. Recorded in the history of the sandeq boat has been proven to be able to sail to Singapore, Malaysia, Japan and Madagascar, Australia and America. 
only in terms of objects or the sandeq boat itself, but also in terms of the rituals or traditions that accompany the formation of the cultural works of the Mandar people, which come from a system of knowledge and values that are firmly held by the Mandar people. In the process of carrying out the ritual, there are symbols that are full of meaning, so it is very important to know the meaning of the symbols of the ritual procession. The symbols contained in the traditional rituals of the Mandar people are not just symbols that are made without meaning, but there are messages to be conveyed through symbolization in the communication process.

The preservation of the Mandar people's material cultural tradition which is carried out every year in the form of a triangular boat race or sandeq race has been carried out but is considered to have minimal meaning. The sandeq boat competition is held as an effort to preserve the marine culture of the Mandar people which is threatened with extinction with the birth of sailing technology which is considered more efficient in meeting daily needs. Therefore, written preservation is considered very necessary to be encouraged, especially reading sources related to the sandeq boat which are considered to be lacking in particular which examines the philosophical meaning of the culture behind a series of ritual processions that accompanies the making of the sandeq boat. In addition, the preservation of written culture must continue to be carried out in order to add references and study materials regarding the richness of the cultural treasures of the Mandar people.

Looking at the literature review about the sandeq boat (Kasitowati, 2011) explains how the sandeq boat is elaborated with Rappo (a traditional fishing tool) as an entity of local wisdom of coastal communities. Fitra et al tried to examine the symbolic meaning of the servant process and navigation techniques on the Mandar tribal sandeq boat (Fitrah et al., 2018). Some of the articles above only explain the symbolic meaning of the finished boat, but the symbolic meaning of the manufacturing process has not been written by many other researchers. Therefore, this article will explain about how belief is the basis for the rituals carried out in the manufacture of sandeq boats, and also see how the symbolic meaning of the traditional sandeq boat-making ritual procession carried out by the Mandar people.

\section{Methods}

This study is an etnographic research. The authors describe and explain clearly what the content of Mandar culture is like and the meaning contained in the traditional ceremonial procession that accompanies the making of the sandeq boat.

Informants were selected using a purposive technique which determines the informants based on representative considerations. Informants come from traditional leaders and the Mandar people community who are considered to have competence or have the ability to understand and know well the intricacies of Mandar people culture, especially in the traditional sandeq boat ritual. 
Table 1. List of Research Informants

\begin{tabular}{clcll}
\hline No. & \multicolumn{1}{c}{ Name } & Age & \multicolumn{1}{c}{ Role } & \multicolumn{1}{c}{ Description } \\
\hline 1 & Quraisy/pua' Hapsa & 58 & $\begin{array}{l}\text { Sandeq boat } \\
\text { builder }\end{array}$ & $\begin{array}{l}\text { He has been engaged in making sandeq } \\
\text { boats for about 25 years }\end{array}$ \\
\hline 2 & Harli/papa' Ke'ling & 48 & $\begin{array}{l}\text { Sandeq boat } \\
\text { builder }\end{array}$ & $\begin{array}{l}\text { Have a lot of experience on boat } \\
\text { building including fisherman's } \\
\text { knowledge and prayer system }\end{array}$ \\
\hline 3 & Nabil & 50 & $\begin{array}{l}\text { Sandeq boat } \\
\text { builder }\end{array}$ & $\begin{array}{l}\text { Experienced in making sandeq boats, } \\
\text { especially for sandeq races }\end{array}$ \\
\hline 4 & $\begin{array}{l}\text { H. Muh. Tharib } \\
\text { Alwi/papa' Mia }\end{array}$ & 59 & $\begin{array}{l}\text { Religious } \\
\text { leaders/annangg } \\
\text { uru }\end{array}$ & $\begin{array}{l}\text { A respected religious figure in the } \\
\text { Pambusuang village area and often } \\
\text { trusted by fishermen to lead rituals }\end{array}$ \\
\hline 5 & Anhar & 45 & $\begin{array}{l}\text { Ponggawa lopi/ } \\
\text { boat captain }\end{array}$ & $\begin{array}{l}\text { Experienced boat captain who brought } \\
\text { the sandeq boat to Japan in 2007 }\end{array}$ \\
\hline 6 & M. Ridwan Alimuddin & 38 & $\begin{array}{l}\text { Mandarin writer } \\
\text { and cultural } \\
\text { observer }\end{array}$ & $\begin{array}{l}\text { He has conducted research on sandeq } \\
\text { and Mandar maritime culture since } \\
\text { 2003 and has published several books }\end{array}$ \\
\hline
\end{tabular}

Source: primary data

This research was conducted through cultural exploration and in-depth interviews. The criteria that have been determined in this study are:

a. Traditional leaders who understand Mandar customs and are willing to provide information about traditional ceremonies or ritual processions in traditional sandeq boats.

b. The boat crew (passandeq) consisting of a captain or leader commonly referred to as a retainer and boat helmsman or mustard lopi in charge of regulating the direction of the sail and the balance of the boat. The passandeq selected are crew members who have worked as a sandeq boat crew for at least a year, and understand the role of the passandeq position and ritual processions in the sandeq boat.

c. A ritual leader or sanro who has experience in the ritual of the sandeq boat for at least the last two years, as well as understanding and knowledge of the traditional ceremonies that accompany the manufacture of the sandeq boat.

d. Sandeq boat builders, are those who have experience making sandeq boats. Knowing the original form of the actual sandeq boat.

The data were analyzed through a qualitative descriptive approach by revealing a description of the research results, after going through the process of analysis and observation into a study that could explain the object or problem being studied. Kriyantono explained that qualitative data analysis started from the analysis of various data that the researchers had collected. (Kriyantono, 2012: 196) The collected data is then classified into categories that have been determined by the researcher. 


\section{Results and discussion}

\section{- Belief as The Basis of Ritual}

The life of the Mandar people, especially those living in coastal areas, is closely related to the sea. The ocean or sasiq (Ocean in Mandar) is considered a place that has mystery and secrets. The sea can give life, offer a variety of goodness but also cause anxiety and even disaster at the same time.

The sea is seen as an area that is believed to have a "guardian" like other places. fishermen assume that "guardian" are supernatural beings who are given power or authority by the Almighty to maintain them. If the "guardian" of the sea is treated well, they will be friendly to people who behave well. On the other hand, if a fisherman makes a mistake or a bad thing, the marine guard will lower his anger, it could be in the form of strong winds, hurricanes, or even strange events that disturb and endanger the safety of the fishermen.

Departing from this understanding, the fishermen believe that all of this cannot be separated from the existence of a great power that dominates everything. Structurally, the ruler of the entire universe is believed to be Puang Allah Ta'ala (the god in Islamic scripture/Allah) to ask for help and pray because of his existence as the ruler of the universe.

The fishermen also believe in the existence of supernatural powers or creatures created by Puang Allah Ta'ala, the belief that in the magical world of the sea there are two names that are believed to be ponggawa in the ocean, namely the prophet Noah and the prophet Khaidir. Noah is believed to be the "prophet of the boat" because in his story which is also contained in the Quran, he was the first to build the largest and strongest boat that ever existed. Then the prophet Khaidir was believed to be the leader and ruler of the entire ocean. Information about the prophet Khaidir was obtained from stories of ancient parents passed down from generation to generation as well as stories about the supernatural experiences of fishermen in the ocean. These stories and experiences have a psychological impact and form a belief of its own for the posasiq Mandar.

In addition to the supernatural powers mentioned above, the posasiq also believe that there are other forces that tend to be evil towards humans. This magical power is believed to be in the form of sea demons or strange animals that can annoy fishermen if they act strangely while in the ocean. It is these mythical stories that then enter the minds of fishermen and try to create a shield so as not to get disturbed while sailing.

Myths make people aware of the existence of miraculous powers. Through myths, humans are helped to be able to appreciate these forces as a force that influences and controls nature and the lives of their communities (Alimuddin, 2013: 100). However, the fishermen also believe that behind the mysteriousness of the ocean and the supernatural power, there are things that can be done as an antidote, including behaviors such as ussul and pamali as well as readings (mantras) that have been practiced by their predecessors. 
- Ussul. Ussul is an understanding or method taken to achieve a certain goal. It may be a little difficult to understand the meaning of ussul, but it is very easy if you look at the ussul practice carried out in the manufacture of sandeq boats.

Ussul has become a habit or tradition among the Mandar people. The behavior or practice of ussul itself is taken from the understanding or paissangang (science) of mystical things or black magic, in other words, ussul is actually the core of black or mystical magic (paissangang) among the Mandar people or also known as doti for the Bugis. But over time, ussul also penetrated into everyday life, not only in the practice of mystical science but in daily activities which are more positive. Ussul is used as an attempt to influence or obtain something.

Ussul has been known by the Mandar people for a long time, since the life of the ancestors of the Mandar people. Ussul was used before the previous people recognized the concept of prayer or asking God. This is closely related to the animist understanding that was known to the public before the emergence of religion in life.

- Pemali. In general, pemali is part of ussul. The difference is that Pemali tends to revolve more around prohibitions or taboos, while ussul can cover the whole of both prohibitions and practices that must be carried out.

Pemali is almost the same for all fishermen, while ussul may differ from one fisherman to another (depending on the understanding or knowledge possessed). Pemali is also learned from the ancestors who passed it down from generation to generation. The fishermen believe that violating the pemali can be disastrous for themselves and their families. For example, when going to sea, fishermen are prohibited from leaving or are advised to delay departure if their belongings or items in the house fall because it is considered a symbol of failure or a bringer of disaster. The solution, fishermen must remain silent, sit down and calm down first before making sure to leave.

\section{- The Symbolic Meaning of Sandeq Traditional Boat Making Ritual Procession}

Sandeq boat is a traditional outrigger boat typical of the Mandar people. With a simple design, this boat, which is usually white in color, has long been the foundation of life for the coastal Mandar people, the majority of whom work as sailors or fishermen.

The word sandeq itself refers to the local language of Mandar which means sharp or sharp. According to the posasiq or Mandar fishermen, this term refers to the shape of the bow of the boat which is tapered and looks sharp like a knife, and the tapered sail or masandeq. Sandeq boat making has been going on for a long time and has been taught from generation to generation by earlier Mandar sailors. Sandeq is a tangible manifestation of the results of learning about nature and the ocean by the Mandar people and how to work together in daily life. 
Making sandeq boats is not simply made like boats or ships today. At every stage of its manufacture, it is accompanied by special activities that make the sandeq boat so special, because the sandeq boat by the Posasiq Mandar is not only seen as a fishing tool but as an "animate" object that will accompany fishermen to go to sea later. The better they treat the sandeq boat, both in the manufacturing process and in its maintenance, the better the results that will be obtained later.

In the process of making sandeq boats, there are a number of ritual activities that are full of symbolic meaning and contain messages both verbally and non-verbally. As a symbolic message, the whole series of rituals for making sandeq boats has a special meaning and message which of course does not appear, especially for people outside the Mandar people. However, the symbolic meaning can be studied and known through further observation.

In general, there are three main ritual stages that accompany the making of a sandeq boat, namely the logging process, the beginning of the manufacturing process, and the launching of the boat. However, technological and scientific developments that have played a major role in changing times have more or less influenced the process of making sandeq boats to this day. Almost all boat work (especially traditional sandeq boats) nowadays do not start with the process of cutting down trees through independent searching in the forest, because now the basic wood for making boats or boats can be purchased directly so that boat builders don't have to bother going to the forest anymore. to cut their own wood.

Today, the main rituals of the sandeq boat can be seen at the beginning of the manufacturing process and after the work is completed or launched into the sea. However, the fishermen call this change as something natural that can be accepted, although it slightly changes the tradition but does not change the cultural essence in the sandeq boat.

It is also important to note that all these ritual activities are carried out for all models of sandeq boats, be it for daily fishing, motangnga (hunting for flying fish), or for racing facilities (sandeq race). In the sense that there is no difference in the implementation of the ritual even though the type of sandeq boat made is different. In fact, this kind of ritual is also carried out for non-boat sailing tools such as large ships or bodies.

\section{- Rituals in the Early Process of Boat Making}

Making sandeq boats begins with the selection of wood as the main material for making sandeq boats. The type of wood is also adjusted to the type of sandeq you want to make. For the type of sandeq boat that is intended for a race (sandeq race), the base wood chosen is strong but light wood. Some types of wood that are usually used include dango, palapi, ma'dang, ti'pulu, and kanduruang.

Along with the times, changes in life are inevitable. Even in traditional boat building, changes are considered as something natural, and more viewed as a readiness to face the future and a response to changing times and technology. 
Changes in the process of making sandeq boats are inevitable and have taken place little by little in the course of time, in the past the selection and preparation of wood was carried out by boat makers and posasiq themselves, namely by exploring the forest, looking for wood trees that suit their needs and felling trees with simple tools. like axes and machetes. But now, the Mandar people prefer to buy directly from wood sellers who also provide the basic wood for making traditional sandeq boats called belang or balakang for boats or lunas for ship.

Many things underlie this process change, ranging from the increasingly difficult to find suitable timber trees in the forest and the distance that is considered to be farther from the coast. In addition, the consideration of time and energy efficiency is also a reason to buy belang directly rather than looking for it in the forest yourself. However, the funds spent will certainly also be greater than looking for wood directly in the forest.

Pande lopi or boatman and posasiq Mandar regard this as something normal. Although leaving the ancestral tradition, this is considered something that is natural and does not interfere with the essence of cultural values in the sandeq boat. This is by no means a bad thing and is even considered a change for the better. The posasiq call it mappalele dalle' (sharing sustenance) because it can indirectly share sustenance with others. All parties involved in making boats including sellers of wood, as well as other boat accessories such as bamboo, rattan wood, tasi' or binding threads, tarpaulins for sails to paint, all parties who provide these goods get their own blessings or sustenance from this traditional boat making activity.

After the preparation of the bottom of the boat has been done, then proceed with the preparation of starting the boat building. Before the boat-building ritual procession is carried out, there are several things to consider before the sandeq boat-making implementation, namely:

a) Determination of the day. Determining the day is one of the most important things in making sandeq boats. For the Mandar community, there are days that are considered good to start an activity or activity, including boat work. Some lopi pande consider Wednesday is the best day to start boat work. Meanwhile, Tuesday is a bad day to start work. Determination of this kind of day has become a tradition and belief handed down from their predecessors which is still used today. Including avoiding Tuesdays, some Mandar people know this from the knowledge of their ancestors. Tuesday in the Mandar language is called allo salasa, almost like the mention of sala-sala (meaning wrong or mistake) so it is considered not good as the beginning of starting a job. The determination of this day is usually determined by an agreement between the ship owner and the boat builder himself, or sometimes the ship owner leaves it entirely to the boat builder when is a good day to start boat work.

b) Preparation of equipment. equipment consists of carpentry tools (parewa) to be used, as well as wood materials for boat construction. Equipment preparation is 
also carried out for serving during the reading-read ritual or thanksgiving procession before the work in order to ask for safety and blessings during the boat-building process.

c) Readiness of pande lopi (boatman). The readiness of the boatman is a must in the boat building process. This is because the sandeq boat is seen as something sacred and must be treated well and carefully, and will determine life in the ocean which incidentally is an area for finding the life of the Mandar fishermen. The new boatman will start working on the boat when he feels physically and mentally ready. The boatman needs to calm his heart and mind first and purify his heart (mapute ate or clean heart) so that there is not the slightest doubt in his heart during the boat building process.

After all of the above have been met, then the sandeq boat work can be carried out. The process of making the boat begins with a thanksgiving event or reading-reading, usually abbreviated as mambaca. This procession is the initial process before "touching" the bottom of the boat.

The mambaca procession is an activity to offer prayers of salvation to God Almighty so that all involved in the boat making process will always be given health and safety during the construction of the boat, as well as blessings for the boat to be built. Processions like this usually have become a tradition and have often been carried out by the Mandar people in certain other situations such as matto' do (building a house) or just about to enter a new house.

As in general rituals, there are always complementary materials that are the main prerequisites, as if the ritual implementation has no meaning if there are no such materials. These offerings have symbolic value or special meaning for posasiq, including:

a) Sokkol, a typical food made from glutinous rice (parepulu'), prepared in three kinds, namely white, black and red. Sokkol food is a symbol of prosperity and hope that the boat can bring abundant results.

b) Kue cucur is a typical food in the form of a flat round made of brown sugar, as a symbol of sweetener so that every work always bears sweet fruit (success).

c) Eggs as a symbol of determination.

d) Several types of bananas (loka), such as loka manurung or kepok bananas as a symbol of respect or position (to manurung), loka tira' or ambon bananas as a symbol of enthusiasm or agility (matira'), and loka warangang or baraan bananas as a symbol of hope abundant or abundant yields (burns).

e) Undung (incense) as a symbol of fragrance, on the basis of the assumption that Islam (the religion of the majority of the Mandar people) likes things that smell good or fragrances.

f) Serving food and cakes for the guests who attend. 
The procession of mambaca is carried out according to the ability of the owner of the boat. Sometimes it is done simply and sometimes it is carried out on a large scale. This is because the costs of production and preparing the offerings are not cheap, especially considering their main job as fishermen.

The reading-read procession is usually led by a religious figure or an annangguru as a prayer leader, and is attended by the boat builder, the boat crew who will later use the boat, and also the local community who are also invited to this activity.

The mambaca procession is a sacred activity, just like other worship activities such as prayer. In the reading process, all parties involved must contemplate, humble their hearts and minds, ask God for all goodness in starting the boat construction, starting from safety until the boat is finished, safety at sea, and asking for sustenance to God Almighty.

Led by annangguru, all parties offer a prayer of salvation to the Almighty and greetings to the Prophet Muhammad SAW. And the most important and always done in these kind of processions is the reading of barazanji. For the Mandar people, the reading of barazanji has become a tradition or even a necessity in every important procession, for example in aqiqah events, entering a new house, or takziah events.

After reading the barazanji and praying, the procession then continues by blessing the parewa or carpentry equipment that will be used. Annangguru captured the smoke of the undung that had been burned earlier and rubbed carpentry tools three times while reading a prayer in his heart. Wiping the smoke of undung three times following the teachings of Islam which likes odd numbers, besides that odd numbers are also the sunnah of the apostle, which is often used daily, such as ablution which is sunnah to rub water three times in each stage.

The carpenter then takes the machete that has been prayed for and brings it to the boat pad where the base wood (belang) is seated to start the first slash. Beginning with silence, the carpenter reads a prayer that is believed to be before hitting, then the carpenter recites a mantra:

"Bismillahirrahmanirrahim. Nurung Muhammad, alai tongang- tonganmu, perauanga' dale di puang allah ta'ala".

meaning:

"Bismillahirrahmanirrahim. Prophet Muhammad, show your determination/sincerity, ask for sustenance (for us) the head of Allah Ta'ala"

Then the machete is struck around the belang counterclockwise like circling the $K a^{\prime} b a h$ in the Hajj ritual, starting from the back, then shifting in the middle and finally at the front of the wood, each being hit 3 times. After that, the craftsman will give a sign by saying "malami tau ma'jama" (work can begin) as a sign that the boat work 
can be carried out. The mambaca event then ended with a meal with the dishes prepared by the host.

For some other fishermen, there is an additional procession in this ceremony. Before hitting the machete on the bottom of the boat, they usually also bless the belang by rubbing the smoke of incense on the base wood (as in blessing the parewa), while reading a prayer that is believed in their hearts. This is done as a form of introduction to the wood that will be used, so that the boat will have a long life and always bring sustenance. The posasiq consider this act as a substitute for the tree-cutting ritual which is no longer carried out. Because they do not touch the tree directly, the belang that are ready to be worked on need to be blessed first.

\section{- Rituals In the Process of Making Boats}

After the initial ritual is carried out, then the implementation of boat building can be carried out. In the manufacturing process, there are no special rituals carried out, but more emphasis on the treatment of the boat, especially the ussul-ussul which is important in making boats. This is in accordance with the understanding of each boatman, because each craftsman has his own understanding, knowledge (paissangang) and prayers in doing his work.

From the confession of several pande lopi, there are several important stages during the boat building process. This stage is considered important because this stage is decisive and is an important part of the sandeq boat. There are implied meanings in the following stages, especially the use of certain mantras and the practice of using ussul in its implementation.

\section{a) The Mattobo Process}

The mattobo process is the process of installing wooden boards as boat walls. This process is carried out after the completion of the belang. Belang that have been trimmed and smoothed into the bottom of the boat, then the boards will be connected to the walls of the boat from the bow to the stern.

The work on tobo (the name for the board for the boat wall) is not carried out immediately, but must be started by the boatman himself. Because it is the carpenter who understands the etiquette of installing tobo, including prayers that are said so that the whole process becomes perfect and good.

Installation of the tobo begins with the installation of a board on the bow or front of the boat. After the preparations are complete and the boards are ready to be installed, the carpenter takes a silent stance while holding the wood to be installed, then reads a prayer silently: 
"Bismillahirrahmanirrahim, sipaangkana Allah Ta'ala, arajanganna Allah ta'ala, sipaelo'ullena Allah ta'ala"

meaning:

((Bismillahirrahmanirrahim, (really true) Allah the Exalted, the Most Great belongs only to Allah SWT, by the will and ability of Allah SWT (so that this boat can be made))

After that the first wood began to be paired. It doesn't stop there, the connection between the first and second boards is not done arbitrarily but is done with certain manners. In the joints of the boards, the carpenter inserts certain objects such as iron plates from old/ancient pans that have been used for a long time. This is where the practice of using ussul in boats can be seen. Iron was chosen because it is strong and not easily damaged with the hope that the connection of the boards will also inherit these properties, strong and durable. Besides that, the carpenters also believe that inserting iron can be interpreted as a shield for the boat from witchcraft or paissangang (black magic) by people who want to mean evil to the boat or the boat owner. This is also believed to be a relief for sailors when they sail the ocean because the boat has been equipped with a shield so that it can ward off bad things in the ocean later.

In addition to iron plates, some carpenters sometimes insert coins or even gold in their boards, with the intention that the sustenance obtained from this boat is abundant and blessed like money or gold is valuable, has a high value, and is a symbol of stability or prosperity.

The use of this kind of suggestion is in accordance with the understanding of each carpenter because there are no special rules made in the practice of ussul or understanding of boat building like this, all purely from the understanding of each pande lopi or carpenter obtained from the results of learning or science studied. But what is clear is that everything will lead to one goal, namely safety and sustenance, be it the safety of the boat, the safety of sailors, to the safety of sailing in the ocean later.

The mattobo process is a very important process for the sandeq boat, because this is the form of the sandeq. It is also important in the mattobo process is the arrangement of the boards that must be balanced on both sides of the boat. The knowledge system or ussul adopted by Posasiq Mandar, strictly prohibits the manufacture of boats that are not in accordance with the actual sandeq boat design. This is considered as something that can hinder sustenance and endanger the safety of the boat driver.

Installation of wooden planks that are careless or irregular also makes some ponggawa lopi reluctant to take the boat sailing because it is considered to be a safety hazard, and is also a futile job because the sustenance obtained will be less or less blessed because it is made carelessly. 
In the mattobo process, the connection of the boards is always attempted to be parallel and similar to both the right and left side of the boat. Although not so symmetrical, the arrangement of the boards must be appropriate and parallel (sippatu) between the joints of the boards on both sides. The unbalanced arrangement of boards (andingang sippole-poleang) is believed to affect the income of marine products.
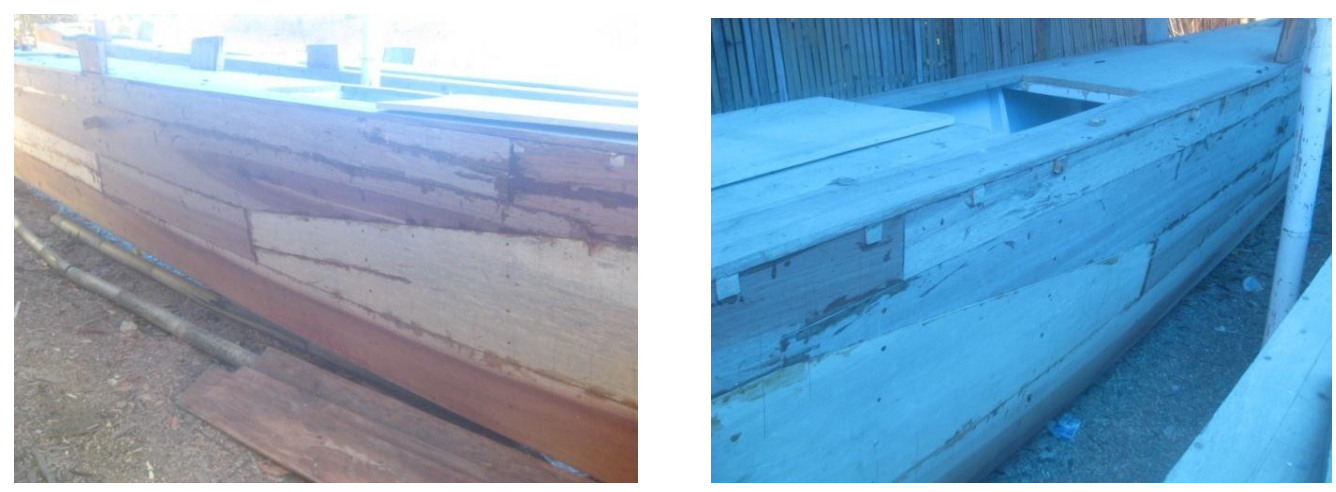

Figure 1. Boat board mounting model Installation of similar boards on both sides and resembles the palm of the hand.

In Mandar language, andingang sippole-poleang means not meeting each other. This is understood both from the arrangement of boards that do not meet each other to the right and left, also between sailors and fish will not meet each other in the ocean if the shipbuilding in this case the arrangement of the boards do not meet each other on both sides. In addition, the arrangement of the boards from the bottom up is arranged according to the palm of the hand so that the arrangement of the boards is stronger like an arrangement of alternating bricks, rather than being arranged in a straight line. This is where the practice of ussul applies, and is believed to have an impact on fish catches. The posasiq say that boats whose planks are not arranged like that are not good for use, both for safety and sustenance (andang mepameang apa' nasalai: not producing sustenance because of wrong (installation))

b) Installing pallayarang (sail mast).

Installation of the mast is carried out after the entire body of the boat has been completed, including the west and palatto (outrigger) of the boat. The installation of the mast indicates that the boat-building process is almost complete.

For some pande lopi, the process of installing a sail pole or mattakir is not accompanied by certain prayers but is strengthened by the practice of using ussul. The mast itself is taken from a special type of bamboo, namely pattung bamboo, a type of bamboo with longer strands, wider diameter, and stronger 
than bamboo in general. This kind of bamboo is usually obtained from the interior of the forest in Mamasa district or from Toraja and Enrekang districts.

Before the mast will be installed, the hole in the mast (peloang) is first filled with several items such as pussu anjoro (young leaves of a newly grown head tree) and cross leaves (nipa leaves). These two objects were chosen because they are flexible and difficult to break. This is where the practice of ussul is used on the mast. Carpenters assume that flexible objects will not break because only hard objects will break easily. This proposal brings hope that the mast will inherit the property of not being easily broken by the object in addition to the strong nature of pattung bamboo.

In addition to using ussul in the form of objects, boat builders also use ussul in the form of behavior. When installing the screen or mattakir, the carpenter is not allowed to touch the hinge joints of the body, especially the wrists, elbows and knees. This suggestion is interpreted that the hinges on the body do not match the strong and hard character of the mast, unlike the elbows and knees which can be bent or broken. It is hoped that the mast can be durable, strong and not easily broken, because it is the mast that will support the sails from the brunt of the wind to storms in the ocean.

At each stage of the work, the boatman always begins the action by saying basmalah. The pande lopi consider that there is no other word of a higher degree when they are about to do something work than saying basmalah. With the words "bismillahirrahmanirrahim" the mast is then attached to the available peloang (pole hole).

Almost at all stages of the process of making a sandeq boat, we must use ussul as an element of boat reinforcement. Whether it's installing the Baratang and Palatto (outrigger/balancing the boat) to the binding on each wood and bamboo, everything uses a certain ussul. Even though there are no special readings or mantras that are said, this whole symbolic act is a prayer that is not recited but believed in the heart. Ussul is a posasiq Mandar way of asking God through actions or behaviors that involve objects that have symbolic meaning.

\section{Conclusions}

In the ritual process of making sandeq boats, there are many things that are expressed through symbols that represent certain meanings and can only be understood by the Mandar people who do the rituals themselves. The use of these symbols has been studied and has become a hereditary tradition among the Mandar people. In addition to containing the meaning to be conveyed, these symbols also emerge from the noble values that are held to this day. As we have seen from the series of stages of rituals that have been described previously, the religious value of the Mandar people is very clear and dominantly seen in the ritual processions carried out. The meeting of Islam and local traditions of fishermen is a form of Islamic acculturation and is a creative reciprocal process. 
In addition to believing in God/Allah SWT as the main force of the universe, Islamic prophets who are considered to have qualified abilities are used as part of the fishermen's spells. Prophet Noah as a prophet who has a close relationship with the sea and is also believed to be the first person to make a large boat (ark). The prophet Khaidir as a unique prophet in Islamic history was appointed as the ruler of the ocean to replace the traditional sea ruler, as well as several prophets who had wealth and privileges such as the prophet Sulaiman, the prophet Ilyas and the prophet Muhammad were included in the minds of the fishermen.

The use of Islamic pronunciations such as basmalah, shahada, shalawat, and walyatalattaf side by side with local pronunciations shows an equal dialogue between Islam as an external value and local wisdom as the main value in society. As a result of this Islamic acculturation, people can accept Islam as a religion that does not completely change the traditions of their ancestors.

Although this influence did not change the magical structure of the boat ritual procession, the change and enrichment of the mantra or ritual has also changed the basis of their magical view of the boat from animism to Islamism. This process will certainly continue towards the true influence of Islam. Meanwhile, aspects of engineering expertise, such as boat building, absorb more of western technology (such as boat motorization). Thus, the sandeq boat in contact with world culture has been able to accept new elements as dynamic factors in its development. Meanwhile, traditional values such as the spirit of togetherness, brotherhood, mutual cooperation and tolerance are more visible in the process of working on boats to daily sailing activities. Even though the boat building only involves a chief handyman and two or three people who help him, almost everyone around him helps in making the boat. The value of brotherhood among the Mandar people is so intimate, that there is no opportunist or egoism among them. Although they do not have a share in the boat, it is the value of brotherhood that makes them move to help each other without expecting anything in return. Because they believe, humans cannot live without the help of others, and at any time they will need that help.

The noble qualities of the Mandar people such as courage, tenacity, agility, and humility, are manifested in the behavior of each posasiq in their daily lives. The shape of the white sandeq boat is a symbol of the purity of heart and humility inherited by the Mandar people. The nature of courage, tenacity, and spirit is manifested in the daily posasiq behavior of fighting against the ocean currents to support his family.

\section{Acknowledgement:}

The author would like to thank the research expert informants (the sandeq boat builders, religious leaders, Ponggawa lopi, as well as writers and observers of Mandar culture). The author also thanks the reviewers and editors of the journal ETNOSIA for their reviews and evaluations for the quality of this article.

\section{Conflicts of Interest:}

The authors declares there is no conflict of interest in the writing of this article. 


\section{References}

Alimuddin, M. R. (2013). Sandeq :Perahu Tercepat Nusantara. Yogyakarta: Ombak.

Bungin, B. (2006). Sosiologi Komunikasi: Teori, Paradigma, dan Diskursus. Teknologi Komunikasi di masyarakat. Jakarta: Kencana pernada Media. Group. Jakarta: Kencana Prenada Media Grup.

Dali, Z. (2016). Hubungan Antara Manusia, Masyarakat, Dan Budaya Dalam Perspektif Islam. Nuansa, IX(1), 47-57. Diambil dari https://ejournal.iainbengkulu.ac.id/index.php/nuansa/article/viewFile/373/32 $\underline{0}$

Darmawan, K. Z. (2008). Penelitian Etnografi Komunikasi: Tipe dan Metode. Mediator: Jurnal Komunikasi, 9(1), 181-188. https:// doi.org/10.29313/mediator.v9i1.1142

Fatanti, M. N., \& Tuti, S. N. T. (2020). Interpretation of Nyadran Sonoageng Ritual as the Form of Ritual Communication of Sonoageng Villagers, Nganjuk Regency. Komunikator, 12(1). https:// doi.org/10.18196/jkm.121036

Fitrah, A. N., Wahyuni, S., Idris, N., \& Bahfiarti, T. (2018). Analysis of Symbolic Meaning of Shipping Technique and Navigation: Case Study of Sandeq Boat of the Mandar Tribe, 165(Iccsr), 316-320. https:// doi.org/10.2991/iccsr-18.2018.70

Hendro, E. P. (2020). Simbol: Arti, Fungsi, dan Implikasi Metodologisnya. Jurnal Ilmiah Kajian Antropologi, 3(2), 160.

Ismail, A. (2012). Agama Nelayan "Pergumulan Islam Dengan Budaya Lokal." Yogyakarta: Pustaka Pelajar.

Juliadi, Cangara, H., \& Bahfiarti, T. (2018). Semiotika Simbol Komunikasi Non Verbal Jamaah Annadzir Dalam Menyebarluaskan Ideologi Islam Di Kabupaten Gowa. KAREBA: Jurnal Ilmu Komunikasi, 7(1), 150-157.

Kasitowati, R. D. (2011). SANDEQ DAN ROPPO Kearifan Lokal Suku Mandar Pesisiran, Sulawesi Barat. Sabda: Jurnal Kajian Kebudayaan, 6(1), 63. https://doi.org/10.14710/sabda.v6i1.13305

Kriyantono, R. (2012). Teknik Praktis Riset Komunikasi (1 ed.). Jakarta: Kencana Prenada Media Grup.

Kusuma, A., Putri Purbantina, A., Nahdiyah, V., \& Khasanah, U. U. (2020). A Virtual Ethnography Study: Fandom and Social Impact in Digital Era. ETNOSIA : Jurnal Etnografi Indonesia, 5(2), 238-251. https://doi.org/10.31947/etnosia.v5i2.10898

Pujiwidodo, D. (2016). TRADISI SLUP-SLUPAN Akulturasi Islam dan Budaya Jawa di Rembang Jawa Tengah. Sabda: Jurnal Kajian Kebudayaan, 11(2), 53-64. https://doi.org/10.14710/sabda.v11i2.16046

Rahmawati, R., Nurhadi, Z. F., \& Suseno, N. S. (2017). Makna Simbolik Tradisi Rebo Kasan. Jurnal Penelitian Komunikasi, 20(1), 61-74. https://doi.org/10.20422/jpk.v20i1.131

Setiadi, E. M., Hakam, K. A., \& Effendi, R. (2013). Ilmu Sosial \& Budaya Dasar. Jakarta: Kencana Prenada Media Grup.

Syan, M., \& Hamdat, S. (2019). Manca': A Study of the Martial Arts' Symbol as Makassar Cultural Identity in Gowa, South Sulawesi. ETNOSIA : Jurnal Etnografi Indonesia, 4(2), 193. https://doi.org/10.31947/etnosia.v4i2.7670 